\title{
TINGIV KÕNEVIIS VIISAKUSE VÄLJENDAJANA EESTI BI - JA B2-TASEME ÕPPIJAKEELES
}

\author{
Mare Kitsnik
}

Tartu ülikool

Ülevaade. Artiklis vaadeldakse tingiva kõneviisi konstruktsioonide kasutamist viisakuse väljendajana B1- ja B2-taseme kirjalikus õppijakeeles. Uurimismaterjaliks on eesti keele kui teise keele riiklike eksamite kirjutamisosa sooritused: eri tüüpi kirjad ning jutustavad ja arutlevad tekstid. B1-taseme tekstides on olnud vähem võimalusi tingivat kõneviisi kasutada, kuid ka võimaluse korral on B1-tasemel olijad eelistanud sageli kindlat kõneviisi. B2-taseme tekstid on võimaldanud rohkem tingiva kõneviisi kasutust ning B2-tasemel olijad on seda võimalust ka kasutanud, arvestades seejuures teksti formaalsusastet ja situatsiooni institutsionaalsust. Kõige sagedamini esineb tingiv kõneviis B2-tasemel ametiasutuste poole pöördudes ehk formaalset laadi ja kõrgema institutsionaalsusega kirjades. Seega on tingiva kõneviisi kasutamine viisakuse funktsioonis seotud kultuuripõhiste keelelise viisakuse normidega. Tingiva kõneviisi kasutamispädevus on B2-tasemel võrreldes B1-tasemega tõusnud, mille peamise põhjusena võib oletada kultuuri- ja keelekeskkonna mõju.

Võtmesõnad: teise keele omandamine, eesti keel teise keelena, kirjalik keel, keelekonstruktsioonid, distantseeriv viisakus

\section{Sissejuhatus}

Keeled kui sümboliliste konstruktsioonide võrgustikud on tekkinud aja jooksul inimeste reaalelu tunnetamise ja kogemuste omavahelise jagamise põhjal. Konstruktsioonid on keelelised üksused, milles sõnavara ja grammatilised vormid on põimunud ning mida iseloomustab vormi ja tähenduse ühtsus. Konstruktsioonid on mõjutatud reaalsusest - need tähistavad inimesi ümbritsevaid nähtusi ning inimeste tundeid, mõtteid ja soove nende kohta. Samal ajal 
mõjutavad konstruktsioonid ka reaalsust - nähtuste nimetamisega luuakse neid ja täidetakse need sisuga. Reaalse elu toimimise tavad ning nende kirjeldamiseks ja mõtestamiseks mingi keele abil loodud tekstid moodustavad inimkultuurid. Seega on keeled ja kultuurid omavahel lahutamatult seotud (Ellis, Larsen-Freeman 2009, Ellis 2008, Larsen-Freeman, Cameron 2008, Larsen-Freeman 1997, 2006, 2007, de Bot jt 2007, Firth, Wagner 1997).

Keelte üldiseks põhifunktsiooniks on inimeste koostegevuse reguleerimine nii, et kõigi soovid ja eesmärgid saaksid võimalikult hästi täidetud. Koostegevuse edukaks reguleerimiseks ei piisa sageli otsesest infovahetusest, vaid on vaja ka suhtlemist hõlbustavaid lisavahendeid. Oluliseks eri kultuurides kasutatavaks lisavahendiks on keeleline viisakus, mille üheks väljendusvahendiks on paljudes keeltes tingiv kõneviis. Keelt omandades omandavad inimesed lisaks konstruktsioonide vormile ka nende tähenduse (kuidas teised keelekogukonna liikmed neid vorme üldiselt mõistavad) ning suhtlusfunktsiooni (mis eesmärgil neid konstruktsioone üldiselt kasutatakse) - sama kehtib ka keelelise viisakuse kohta.

Keeleomandamine toimub suures osas kasutuspõhiselt (LarsenFreeman 1997, Ellis 2002, Tomasello 2003, MacWhinney 2004, Eskildsen 2008, Verspoor, Behrens 2011) ning osaliselt ka teadliku õppimise teel. Teise keele omandamist mõjutavad lisaks ka juba omandatud esimese keele konstruktsioonid ning üldised teadmised maailma toimimise kohta (Kaivapalu 2005, Ringbom 2007). Et eesti keele kui teise keele omandamisprotsessi paremini toetada, on vaja täpsemalt mõista selle seaduspärasusi. On vaja senisest põhjalikumalt kirjeldada, kuidas arenevad eesti keele konstruktsioonid: milliste keeleliste vormidega mis tähendusi mingil keeleoskustasemel A1-C2 väljendatakse ja mis suhtlusfunktsioonides neid kasutatakse. Seejuures on huvitav ja vajalik mõista, kuidas on konstruktsioonide omandamine seotud kultuuriga ning kui suur roll on konstruktsioonide omandamisel kasutusel ja kui suur osa teadlikul õppimisel.

Olen varem uurinud, kuidas arenevad keelekonstruktsioonid kahel keeleoskuse arengus kesksel, B1- ja B2-tasemel (Kitsnik 2014, 
2015, 2017, 2018). Seejuures on selgunud, et üheks B1- ja B2-taset eristavaks indikaatoriks on tingiva kõneviisi konstruktsioonide areng ning tingiva kõneviisi levinuim suhtlusfunktsioon õppijakeeles on viisakuse väljendamine (Kitsnik 2014, 2015). Artikli aluseks olevas uuringus olen üksikasjalikumalt vaadelnud ka oma varasemates uuringutes kasutatud B1- ja B2-taseme kirjutamisosa tekste. Seekord olen keskendunud tingiva kõneviisi konstruktsioonide kasutamisele distantseeriva viisakuse väljendajana: uurinud nende konstruktsioonide seost teksti autori ja saaja tuttavusastme, sotsiaalsete positsioonide sarnasuse, esitatava palve iseloomu, situatsiooni institutsionaalsuse jmt kultuuripõhiste keelelise viisakuse normidega. Artikli esimeses osas annan teoreetilise lühiülevaate keelelise viisakuse mõistest üldisemalt ja teises osas tingivast kõneviisist keelelise viisakuse väljendajana. Kolmandas osas kirjeldan artikli aluseks oleva uurimuse materjali ja metoodikat. Artikli neljandas osas esitan uurimistulemused ning viiendas osas teen kokkuvõtte ja arutlen uurimistulemuste tähenduse üle.

\section{Keeleline viisakus}

Viisakus on sotsiokultuuriliselt määratud käitumine, mille eesmärk on tegutseda sobivalt, et tekitada või säilitada häid suhteid grupi (suurema kultuurikogukonna või väiksema rühma, kuhu kuulutakse) liikmete vahel (Watts 2003). Viisakus põhineb suhtlejate vastastikusel teineteisega arvestamisel. Sellega näidatakse, et ei taheta kahjustada vestluskaaslase minapilti ega mõjuda talle häirivalt (Brown, Levinson 1987), mis aitab kaasa suhtluseesmärkide saavutamisele. Viisakuse väljendamise sagedase vajaduse tõttu on kultuurikogukondades omavahelise suhtlemise käigus selleks välja kujunenud spetsiaalsed keelelised vahendid. Keelelise viisakuse vormid ja nende kasutusnormid on eri keeltes osaliselt sarnased, osaliselt mõnevõrra erinevad ning neid jagatakse üldiselt kahte tüüpi: lähendav ja distantseeriv viisakus (Brown, Levinson 1978). Lähendavat viisakust kasutatakse tavaliselt mitteformaalsemates olukordades ja 
tuttavamate inimestega. Selle eesmärk on rahuldada inimeste gruppi kuulumise vajadust ehk vähendada psühholoogilist distantsi enda ja suhtluspartneri vahel. Selleks kasutatakse meie-vormi, grupisisest slängi, hüüdnimesid, ainult oma seltskonnale mõistetavaid nalju jmt.

Distantseerivat viisakust kasutatakse üldjuhul formaalsemates olukordades ja võõramate inimestega suhtlemisel, kui soovitakse panna vestluspartner midagi tegema, mingil viisil käituma. Et käsud ja palved on teise inimese minapilti ohustavad tegevused, millele adressaat võib ebasoovitavalt reageerida, on neid vaja kuidagi pehmendada või kaugemalt esitada. Selleks suurendatakse vestluskaaslaste vahelist keelelist distantsi (vabandatakse, juhatatakse info sisse, nt Ma tahaksin küsida, kas ...?, kasutatakse mitmuse vorme). Samuti tehakse vestluspartnerile palve täitmisest keeldumine kergemaks (esitatakse küsimus otsese soovi asemel, nt Kas te aitate mind?). Veel mõjub viisakamalt kaudsete vahendite kasutamine otseütlemise asemel (nt modaalkonstruktsioonid Kas te saate mind aidata?), pessimismi väljendamine (nt Ega te ei saa mind aidata?), ebareaalsuse väljendamine (tingiv kõneviis, nt Kas te saaksite mind aidata?). Viisakuse väljendamisel kasutatakse sageli mitut vahendit koos, mis tõstab üldjuhul viisakuse astet - nii mõjub Kas te saaksite seda teha? (küsimus + modaalverb + tingiv kõneviis) veidi viisakamalt kui Kas te teeksite seda? (küsimus + tingiv kõneviis) (vt Klaas-Lang, Pajusalu 2016). Samas ei tohi viisakus olla konteksti sobimatult suur.

Distantseeriva viisakuse vahendeid kasutatakse üldjuhul rohkem siis, kui teate edastaja ja vastuvõtja ei ole tuttavad; kui teate vastuvõtja sotsiaalne positsioon ja vanus on teate edastaja omast kõrgemad; kui teate edastaja soovib teate vastuvõtjalt suurt teenet; kui teate vastuvõtja on kohustatud teatele reageerima või midagi tegema ehk situatsiooni institutsionaalsus on kõrge; kui teate edastaja soovib väga oma soovi täitumist; kui teate saajal on raske teate edastaja soovi täita; kui teate edastaja tunneb, et tal ei ole suurt õigust oodata oma soovi täitmist (vt Curl, Drew 2008, Klaas-Lang, Pajusalu 2016).

Viisakuse väljendamine on mõjutatud kultuurist - see määrab, mida peetakse antud kogukonnas viisakaks, milliseid vahendeid ja 
millal on sobilik kasutada. (Mills 2003, Klaas-Lang, Pajusalu 2016). Et teada, kuidas mingis situatsioonis peaks käituma, on seega vaja vallata keelelise viisakuse väljendamise vahendeid ning tunnetada kultuurinorme. Seejuures võivad mõned keelelise viisakuse väljendamise vahendid eri kultuurides olla eri mõjuga ka siis, kui nad on pealtnäha sarnased. Sujuvalt saab keelelise viisakuse vahendeid seega kasutama õppida vaid kultuurikeskkonnas suheldes. Kui teise keele omandajail on sellist võimalust liiga vähe, võivad nad mõnikord kasutada grammatiliste reeglite kohast keelt, mida esimese keele kõnelejad tajuvad ometi ebaviisakana (House 2008).

\section{Tingiv kõneviis viisakuse väljendajana}

Artiklis keskendun distantseeriva viisakuse väljendamise ühele levinud vahendile - tingiva kõneviisi kasutusele. Tingiva kõneviisi üldine funktsioon kõigis keeltes on vastanduda kindlale kõneviisile. Kindla kõneviisiga väljendatakse tegevuste või sündmuste reaalset toimumist. Tingiva kõneviisi kasutamine märgib aga sündmuste või tegevuste ebareaalsust (üldiselt või antud hetkel ja kohas) ning paigutab need suhtlejatest näiliselt kaugemale. Eesti keeles võib tingiva kõneviisi tähendused jagada kaheks suureks rühmaks (Metslang 1999). Esimene rühm väljendab niinimetatud raamitähendust - sel juhul tähendab tingiv kõneviis seda, et kuigi sündmus või tegevus on hetkeseisuga mittereaalne, muutuks see teatud tingimuste täitumise korral reaalseks nt Kui mul oleks praegu vaba aega, siis ma läheksin kinno (Metslang 1999). Tingiva kõneviisi teise rühma tähendusi nimetatakse intentsioonitähenduseks - need väljendavad soove ja kavatsusi, nende abil tehakse ettepanekuid ja esitatakse palveid, mille puhul ei ole aga teada, kas ja mis tingimustel need reaalses elus täituvad. Näiteks Ma nii tahaksin praegu kinno minna. Läheks õige kinno! (Metslang 1999).

Tingiva kõneviisi intentsioonitähendus on üks distantseeriva viisakuse väljendamise olulisi viise (Pajusalu, Pajusalu 2004). Muutes väited, ettepanekud, soovid ja palved ebareaalsemaks, tekitatakse 
teate edastaja ja saaja vahele suurem distants ning mõjutakse seega saaja minapildile vähem ähvardavalt. Ebareaaalsus muudab väljendatu ka ebakindlamaks ja pehmemaks ning teate saajal on kergem seda osaliselt või täielikult tagasi lükata. Tingivat kõneviisi kasutatakse viisakusfunktsioonis eelkõige käskude pehmendamiseks ja oma arvamuste enesekindluse vähendamiseks. Sageli esinevad tingivas kõneviisis verbid pidama (peaks), tahtma (tahaks), võima (võiks), olema (oleks). Seejuures väljendab peaks tavaliselt üldisikulist ettepanekut või episteemilist modaalsust, tahaks pehmendatud soovi ning oleks esineb sageli täisminevikku vormistava abisõnana (Pajusalu, Pajusalu 2004).

Renate Pajusalu (2014) on võrrelnud tingiva kõneviisi kasutust mitmes eri keeles ning näidanud, et viisakuse väljendajana esineb tingiv kõneviis kõige sagedamini soome keeles, kõige harvemini vene keeles ning keskmise sagedusega eesti, leedu ja prantsuse keeles. Vene keele omapäraks on, et tingiva kõneviisi eitusvormi kasutatakse rohkem ning see muudab väljenduse veel ühe nüansi võrra distantseerivamaks ehk viisakamaks. Birute Klaas-Lang ja Renate Pajusalu (2016) on uurinud modaalkonstruktsioone eesti- ja soomekeelsetes palvetes ning näidanud, et tingiv kõneviis on soome keeles tugevam ja olulisem palvete vormistamise viisakusvahend kui eesti keeles. Soome keeles on tingiv kõneviis ka selgemalt seotud modaalverbidega, mis esinevad viisakuse väljendamisel peaaegu alati tingivas kõneviisis. Soomekeelsete palvete viisakusvormides esineb ka vähem varieerumist kui eesti keeles ning palve esitamine võõrale ja tuttavale on keeleliselt sarnasem kui eesti keeles.

Tingiva kõneviisi konstruktsioone kui viisakuse väljendamise vahendit eesti keele kui teise keele õppijate kasutuses on uuritud seni napilt. Täpsem info selle teema kohta võimaldaks paremini mõista õppijakeele arengu üldisi seaduspärasusi ning töötada keeleõppijate jaoks välja täpsemaid seletusi ning tõhusamaid harjutusvõimalusi. 


\section{Uurimismaterjal ja -meetod}

Artikli aluseks oleva uuringu materjaliks on eesti vahekeele korpuse (EVKK) materjalide põhjal minu varasemate uuringute jaoks koostatud töökorpused B1-taseme korpus (24 624 sõnet) ja B2-taseme korpus (21 783 sõnet). Korpustes asuvad täiskasvanute eesti keele kui teise keele B1- ja B2-taseme riigieksami kirjutamisülesannete sooritused. Töökorpustesse kuuluvad tekstid, mida riiklikud hindajad on eksamil hinnanud $60-92 \%$-ga maksimumist. $60 \%$ on eksami sooritamiseks vajalik miinimumpiir. Kõige kõrgema hinde saanud tööd olen oma uuringust välja jätnud, et vältida eesti keelt vastavast tasemest tunduvalt kõrgema oskusega isikute tööde sattumist uurimismaterjali hulka: eksamitel käib vahel inimesi, kes valdavad eesti keelt vabalt, kuid kellel on vaja tasemetunnistust töö vm jaoks. Töökorpustes esinevad eri tüüpi tekstid, mida kirjutatakse vastava taseme eksami kirjutamisosas. B1-taseme tekstitüübid on 1) lühikiri (umbes 50 sõna), milles teksti autor jagab töökaaslastele, sõpradele vm teavet mingi ürituse kohta, kutsub kaaslasi kuhugi, teatab neile midagi vmt ja 2) etteantud teemal kirjutatud jutustav tekst ehk miniessee (umbes 120 sõna). B2-taseme tekstitüüpide hulka kuuluvad 1) poolametlik kiri (umbes 120 sõna), milles autor pöördub ametiasutuse poole järelepärimisega, kaebusega, tänuga vmt; annab tagasisidet toimunud ürituse kohta, esitab töökaaslasele küsimuse või palve vmt; 2) etteantud küsitlusandmete põhjal vabas vormis arutlev kokkuvõte (umbes 180 sõna) ja 3) arutlev tekst etteantud teemal, mille kohta peab avaldama poolt- ja vastuargumente ning tegema kokkuvõtte (umbes 180 sõna). Tekstide teemad on igal konkreetsel eksamil erinevad. Varasemas tingiva kõneviisi uuringus (Kitsnik 2015, 2018) olen vaadelnud kõiki vastava taseme tekste koos. Siinse artikli aluseks olnud uuringus olen keskendunud tingiva kõneviisi kasutuse võrdlemisele eri tüüpi tekstides. Seejuures olen kirju ja jutustavaid-arutlevaid tekste vaadelnud mõnevõrra eri viisil, sõltuvalt viisakuse väljendamise erinevast funktsioonist nendes. 
Kirjade uurimisel olen mõlemal tasemel arvestanud nii tekstitüüpe kui ka konkreetseid teemasid. B1-tasemel on sel viisil vaatluse all olnud kolm kirjarühma: 1) teade kolleegidele töölt lahkumise ja uude töökohta tööle asumise kohta; 2) kutse kolleegidele osalemaks asutuse spordipäeval; 3) kutse kolleegile minna koos kontserdile. B2-tasemel on uuritavad kirjade rühmad olnud: 1) kutse kolleegile osalemaks koos täienduskoolitusel; 2) piduliku ürituse saali, toidu ja meelelahutuse tellimus restorani; 3) äraütlemine kolleegile, kes on palunud end ühe päeva tööl asendada; 4) järelepärimine kindlustusfirmale kindlustuse võimaluste ja tingimuste kohta. Tingiva kõneviisi kasutuse analüüsil olen arvestanud järgmisi ülesande situatsioonidest tingitud näitajaid: milline on kirja saatja ja kujuteldava saaja tuttavusaste ning sotsiaalse positsiooni erinevus; kui suurt teenet kirja saatja soovib ja kui oluline soovitud teene tema jaoks on; kas soovitud teene täitmine on kirja saaja jaoks kohustuslik ja kui raske on tal soovi täita. B1-taseme jutustavaid tekste olen uurinud ühe rühmana ilma neid teemade kaupa jagamata ning sama olen teinud ka B2-taseme arutlevate tekstidega. Jutustavatest ja arutlevatest tekstidest olen uurimiseks valinud vaid need tingiva kõneviisi konstruktsioonid, mida teksti autor kasutab oma kirjutamisprotsessi kirjeldamiseks ehk millega ta pöördub teksti lugeja poole ja mida võib seega pidada viisakust väljendavaks.

Uurimismeetodina olen kasutanud korpusest tulenevat (ingl corpus-driven) lähenemist: olen uurinud tingiva kõneviisi konstruktsioone, sest need on korpusest esile kerkinud B1- ja B2-taseme esinemissageduse suure erinevuse tõttu (Kitsnik 2018). Olen leidnud tekstirühmade kaupa kõik tingiva kõneviisi viisakust väljendavad konstruktsioonid - tingivas kõneviisis verbid koos nende lähiümbrusega. Tingiva kõneviisi konstruktsiooni esinemise olen seejuures määranud vastavalt konstruktsiooni peasõna morfoloogilisele tunnusele ning viisakuse väljendamise üle otsustanud kontekstipõhiselt.

Tingiva kõneviisi konstruktsioone olen uurinud nii kvantitatiivselt kui ka kvalitatiivselt. Kirjadest olen leidnud 1) iga tekstirühma kohta tingivas kõneviisis konstruktsioonide üldsageduse tuhande 
sõne kohta ning 2) tingivas kõneviisis esinevate verbide koguarvud ning võrdluseks ka samade verbide koguarvud kindlas kõneviisis. Jutustavatest ja arutlevatest tekstidest olen leidnud tingivas kõneviisis esinevate eri verbide koguarvud ning võrdluseks samade verbide koguarvud kindlas kõneviisis. Kvalitatiivselt olen kirjades analüüsinud tingiva kõneviisi konstruktsioonide distantseeriva viisakuse väljendamise alafunktsioone ning nende seost kultuuripõhiste teguritega: teksti autori ja kujuteldava saaja tuttavusastmega, sotsiaalsete positsioonide erinevusega, teksti autori soovitud teene suurusega, soovi täitmise kohustuslikkusega kirja saaja jaoks, soovi täitumise olulisusega kirja autori jaoks ja soovi täitmise raskusega kirja saaja jaoks. Jutustavates ja arutlevates tekstides olen kvalitatiivselt vaadelnud tingiva kõneviisi alafunktsioone viisakuse väljendamisel. Kokkuvõttes olen analüüsinud tingiva kõneviisi kui suhtlemist hõlbustava keelelise vahendi kasutust B1- ja B2-tasemel seoses kultuuripõhiste viisakusnormidega.

Uurimismaterjal sobib analüüsiks, sest eksamiülesanded on elulised ja funktsionaalsed ning imiteerivad üsna täpselt tegelikus elus ette tulla võivaid suhtlusolukordi. Inimesed on tekstid kirjutanud eksamiolukorras, mis välistab kõrvalise abi kasutamise. Eksamitööde hindamisel arvestatakse ülesande täitmist, teksti sidusust ja keelelist täpsust, kuid ei nõuta ega arvestata konkreetsete keelekonstruktsioonide kasutamist - seega ei ole tingiva kõneviisi kasutust mingil viisil kunstlikult esile kutsutud. Asjaolu, et B1- ja B2-taseme eksamitel kirjutatakse eri tüüpi tekste, võib tekitada küsimuse tekstides kasutatavate konstruktsioonide objektiivse võrreldavuse kohta. Oma töös lähtun asjaolust, et eksamil kasutatavad tekstitüübid iseloomustavad vastava taseme kommunikatiivset keelepädevust, mille väljendamiseks on vajalik ka vastav leksikaalgrammatiline keelepädevus. Keelekonstruktsioonid on samas tekstitüüpidega seotud siiski vaid osaliselt - keerukamad tekstitüübid ei too iseenesest kaasa arenenumate keelekonstruktsioonide kasutust, kui inimene selleks valmis ei ole (Kuiken, Vedder 2012). 
Keelelise viisakuse väljendamine võib nagu teistegi konstruktsioonide kasutamine olla lisaks sihtkeele kultuurikeskkonnale teatud määral mõjutatud ka keeleomandajate esimese keele ja kultuuri keskkonnast. Oma uuringus ei ole ma saanud seda aspekti arvestada, sest mul puudub sellekohane taustainfo. Samas olengi olnud huvitatud peamiselt tasemepõhistest üldtendentsidest keelelise viisakuse arengus. Peab siiski arvestama, et küllalt suure tõenäosusega moodustavad suure osa tekstide autoritest vene emakeelega inimesed, sest nemad on riiklike eesti keele eksami sooritajate hulgas domineeriv grupp. Seega võivad uurimistulemused olla mingil määral mõjutatud vene keele kui esimese keele kultuuritaustast.

\section{Uurimistulemused}

\section{I. TINGIVA KÕNEVIISI VIISAKUST VÄLJENDAVATE KONSTRUKTSIOONIDE ESINEMISSAGEDUS BI - JA B2-TASEME KIRJADES TÜÜPIDE JA TEEMADE KAUPA}

Kõigepealt olen leidnud tingiva kõneviisi viisakust väljendavate konstruktsioonide sageduse tuhande sõne kohta nii B1- kui ka B2-taseme igas kirjarühmas (tüübi ja teema põhjal). Sagedused on esitatud joonisel 1.

B1-tasemel on tingiva kõneviisi sagedus võrdselt madal teates kolleegidele töölt lahkumise kohta (1 kord tuhande sõne kohta) ja kolleegidele saadetud kutses osaleda spordipäeval (1,3 korda tuhande sõne kohta). Mitu korda sagedamini esineb tingiv kõneviis kolleegile kirjutatud kutses, milles kirja saatja kutsub teda koos endaga kontserdile (7,5 korda tuhande sõne kohta). B2-taseme kõigis kirjarühmades on tingiva kõneviisi sagedus kõrgem kui B1-tasemel. Peaaegu võrdne on see kolleegi koolitusele kutsuvas kirjas (8 korda tuhande sõne kohta) ja äraütlevas vastuses kolleegi abipalvele $(8,5$ korda tuhande sõne kohta). Neist kaks korda kõrgem on tingiva kõneviisi sagedus kindlustusfirmale saadetud järelepärimiskirjas (17,2 korda tuhande sõne kohta) ja veel märgatavalt kõrgem restorani piduliku ürituse tellimuskirjas (27 korda tuhande sõne kohta). 


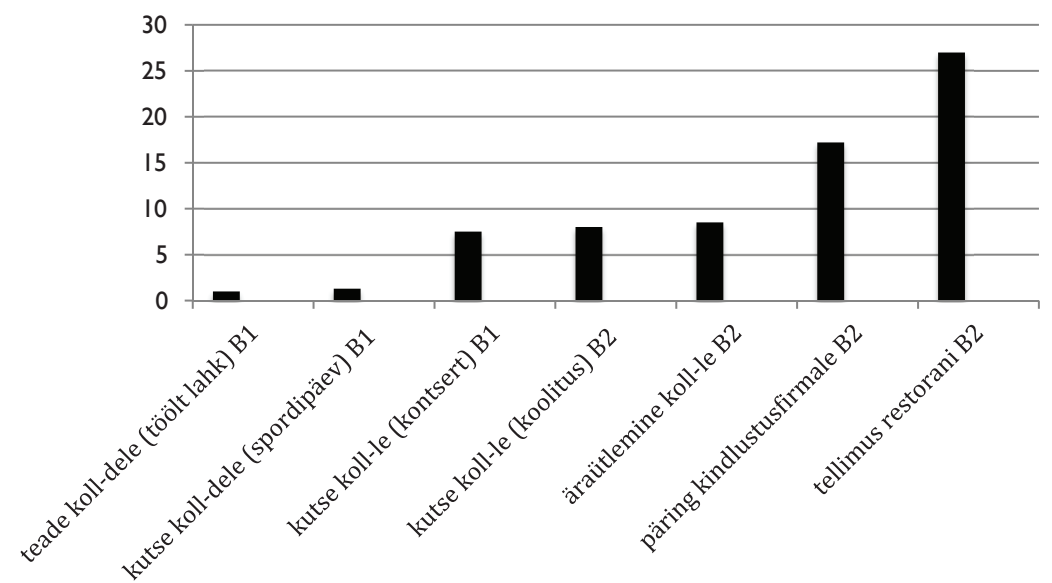

Joonis I. Tingiva kõneviisi viisakust väljendavate konstruktsioonide sagedused kirjade tüüpide ja teemade kaupa. Vertikaaltelg näitab sagedust tuhande sõne kohta

Järgnevalt vaatlen lähemalt tingiva kõneviisi kasutamist igas tekstirühmas, alustades tekstist, milles tingiv kõneviis on madalaima sagedusega, ja liikudes järjest kõrgema sagedusega tekstide suunas. Osas 4.2 on esitatud B1-taseme tekstide analüüs ja osas 4.3 B2-taseme tekstide analüüs. Iga tekstirühma kohta on esitatud ülesande täpsem kirjeldus, tingiva kõneviisi esinemise absoluutarv verbide kaupa, samade verbide kindlas kõneviisis esinemise absoluutarv ning tulemuste analüüs distantseeriva viisakuse seisukohalt koos esinemisnäidetega.

\subsection{TINGIV KÕNEVIIS KUI VIISAKUSE VÄLJENDAJA BI-TASEMEL}

\subsection{TEADE KOLLEEGIDELE TÖÖLT LAHKUMISE KOHTA}

Kirja autor peab ette kujutama, et ta on saanud uue tööpakkumise ja lahkub seetõttu peagi oma praegusest töökohast. Ülesanne on kirjutada kolleegidele teade, milles tuleb neid oma lahkumisest teavitada. Tingiva kõneviisi abil viisakuse väljendamise juhtude arv selles kirjarühmas on esitatud tabelis 1 . Välja on toodud ka samade 
verbide arv kindlas kõneviisis (v.a verbi olema juhud, mille puhul on raske otsustada, millised neist väljendavad viisakust), et võrrelda tingiva ja kindla kõneviisi kasutusdünaamikat.

Tabel I. Tingiva kõneviisi konstruktsioonide ja samade verbide kindla kõneviisi konstruktsioonide esinemissagedus BI-taseme tekstis „Teade kolleegidele töölt lahkumise kohta"

\begin{tabular}{|l|c|c|}
\hline $\begin{array}{c}\text { Tingivas kõneviisis } \\
\text { esinevad verbid }\end{array}$ & $\begin{array}{c}\text { Tingiva kóneviisi esinemis- } \\
\text { juhtude absoluutarv }\end{array}$ & $\begin{array}{c}\text { Kindla kõneviisi esinemis- } \\
\text { juhtude absoluutarv }\end{array}$ \\
\hline olema & $\mathrm{I}$ & ei ole vaadeldud \\
\hline soovima & $\mathrm{I}$ & 3 \\
\hline
\end{tabular}

Nagu tabelist näha, kasutavad B1-tasemel olijad tingivat kõneviisi selles kirjarühmas kokku vaid kaks korda (üks kord verbiga olema ja üks kord verbiga soovima) ehk üks kord tuhande sõne kohta. Ka verbi soovima kindla kõneviisi konstruktsioone esineb selles tekstirühmas vähe: kolm korda. Tekstide autorid kirjutavad inimestele, kellega nad on tuttavad ning eeldatavalt enam-vähem võrdsel sotsiaalsel positsioonil. Kiri ei ole suunatud konkreetsele inimesele, vaid suuremale lugejate hulgale. Situatsiooni institutsionaalsus ei ole kõrge: teate saajad peavad edastatud info teadmiseks võtma, nad ei pea sellele aga otseselt reageerima ega midagi tegema. Ainuke tegevus, mida neilt (osa kirjades) oodatakse, on osalemine väikesel lahkumispeol. See ei ole kellelegi kohustuslik, kuid ilmselt oleks kirja saatjal hea meel kolleege seal näha. Seega oleks lahkumispeole kutsudes olnud sobilik ka tingivat kõneviisi kasutada, seda on aga tehtud vaid üks kord (näide 1).

(1) Sooviksin tuua kaasa midagi sü̈̈а ја juиa.

Samas ei mõju ka kindla kõneviisi kasutamine selles funktsioonis ebaloomulikult. Muudes kirja osades ei oleks tingiva kõneviisi kasutamine sobilik. 


\subsubsection{KUTSE KOLLEEGIDELE SPORDIPÄEVAL OSALEMISEKS}

Kirja autor peab ette kujutama, et ta on asutuse spordipäeva korraldaja. Ta peab kirjutama kolleegidele teate, milles jagab infot spordipäeva kohta ja kutsub töökaaslasi spordipäeval osalema. Tingiva kõneviisi abil väljendatud viisakuse juhtude arv selles kirjarühmas on esitatud tabelis 2. Välja on toodud ka samade verbide arv kindlas kõneviisis, et võrrelda tingiva ja kindla kõneviisi kasutusdünaamikat.

Tabel 2. Tingiva kõneviisi konstruktsioonide ja samade verbide kindla kõneviisi konstruktsioonide esinemissagedus BI-taseme tekstis „Kutse kolleegidele spordipäeval osalemiseks"

\begin{tabular}{|l|c|c|}
\hline $\begin{array}{c}\text { Tingivas kõneviisis } \\
\text { esinevad verbid }\end{array}$ & $\begin{array}{c}\text { Tingiva kõneviisi esinemis- } \\
\text { juhtude absoluutarv }\end{array}$ & $\begin{array}{c}\text { Kindla kõneviisi esinemis- } \\
\text { juhtude absoluutarv }\end{array}$ \\
\hline tahtma & $\mathrm{I}$ & $3 \mathrm{I}$ \\
\hline tulema & $\mathrm{I}$ & 4 \\
\hline võima & 2 & 25 \\
\hline
\end{tabular}

Ka selles tekstirühmas esineb B1-tasemel olijate tekstides tingivat kõneviisi väga vähe: kokku neli korda (üks kord verbiga tahtma, üks kord verbiga tulema ja kaks korda verbiga võima) ehk 1,3 korda tuhande sõne kohta. Verbide tahtma ja võima kindla kõneviisi konstruktsioone esineb selles tekstirühmas tingiva kõneviisi konstruktsioonidest tunduvalt rohkem: kokku 56 korda, verbi tulema kindla kõneviisi konstruktsioone esineb neli korda.

Tingiva kõneviisi konstruktsioone kasutatakse soovituse väljendamiseks (näited 2 ja 3) ning ettepaneku tegemiseks (näide 4).

(2) Ma tahaksin soovita sulle uue spordipäeva.

(3) Sellg tuleks panna dressid spordi jalatsid võiks võtta kaasa veel, vee pudeli mis kustutab janu.

(4) Kokku võiks saada pussi peatuses ja sealt edasi tulemisi tegema.

Selles ülesandes kirjutatakse tuttavatele, sama sotsiaalse positsiooniga inimestele. Kiri ei ole suunatud ühele konkreetsele inimesele, vaid suuremale lugejate hulgale. Situatsiooni institutsionaalsus on 
keskmine. Kirja saajatelt soovitakse teatud tegevust, mis nõuab neilt küllalt suurt aktiivsust. Kirja saatjale on küll oluline, et kirja saajad kindlal viisil tegutseksid, kuid see ei ole vältimatu iga saaja puhul. Kokkuvõttes on seda laadi tekstis tingiva kõneviisi vähene kasutamine üsna loomulik. Tingiva kõneviisi rohke kasutamine võiks teksti muuta liiga ebakindlaks ja vähendada selle soovitavat mõju.

\subsubsection{KONTSERDIKUTSE KOLLEEGILE}

Kirja autor peab ette kujutama, et ta soovis koos kaaslasega kontserdile minna, kuid kaaslane ei saa mingil põhjusel tulla. Seetõttu peab inimene kirjutama kolleegile ja pakkuma talle vabaks jäänud piletit ehk kutsuma teda koos endaga kontserdile.

Tingiva kõneviisi abil viisakuse väljendamise juhtude arv selles kirjarühmas on esitatud tabelis 3. Välja on toodud ka samade verbide arv kindlas kõneviisis, et võrrelda tingiva ja kindla kõneviisi kasutusdünaamikat.

Tabel 3. Tingiva kõneviisi konstruktsioonide ja samade verbide kindla kõneviisi konstruktsioonide esinemissagedus BI-taseme tekstis „Kolleegi kontserdile kutsumine"

\begin{tabular}{|l|l|l|}
\hline $\begin{array}{c}\text { Tingivas kõneviisis } \\
\text { esinevad verbid }\end{array}$ & $\begin{array}{c}\text { Tingiva kõneviisi esinemis- } \\
\text { juhtude absoluutarv }\end{array}$ & $\begin{array}{c}\text { Kindla kõneviisi esinemis- } \\
\text { juhtude absoluutarv }\end{array}$ \\
\hline tahtma & 19 & 45 \\
\hline saama & $\mathrm{I}$ & 16 \\
\hline pidama & 2 & 2 \\
\hline
\end{tabular}

Selles tekstirühmas kasutatakse B1-tasemel tingivat kõneviisi selgelt rohkem kui eelnevalt kirjeldatud kahes rühmas: kokku 22 korda ehk 7,5 korda tuhande sõne kohta. Peamiselt esineb tingiva kõneviisi konstruktsioonides verb tahtma (19 korda), mida kasutatakse ettepaneku tegemiseks. Peamiselt esineb tahtma seejuures väitlauses ja ainsuse esimeses pöördes, rohkem pikas vormis (näide 5) ja vähem lühivormis (näide 6). 
(5) Ma tahaksin sulle pakkuda üks pilet kontserdile Alla Pugatšovale.

(6) Tahaks Sulle pakkuda pileti kontserdile, mis toimub 26. mail Rahvusoopera kontserdisaalis.

Veel esineb verb tahtma veidi ainsuse teise pöörde pikas vormis. Ka selle vormiga tehakse ettepanek, mis esineb nii väitlausena (näide 7) kui ka küsilausena (näide 8).

(7) Ma arvasin et äkki tahaksid tulla sest sedasugune muusikat meeldib sulle.

(8) Kas sa tahaksid koos minuga kontserdile minna?

Ettepaneku tegemiseks kasutatakse tahtma-konstruktsioone aga ka kindlas kõneviisis ja koguni 2,4 korda sagedamini kui tingivas kõneviisis (näide 9).

(9) Mul on üks pilet kontserdile ja ma tahan seda pakkuda teile.

Kaks korda esineb tingiva kõneviisi konstruktsioonides veel verb pidama (näide 10) ja üks kord modaalverb saama (näide 11).

(10) Peaks olema väga tore!

(11) Kas sa ühislikult ei saaks koos minuga minna kontserdile?

Selle ülesande puhul pöördutakse üldjuhul ühe inimese poole, kes on kirja saatjale rohkem või vähem lähedane tuttav. Situatsiooni institutsionaalsus on üsna kõrge, sest kirja kirjutaja soovib panna kirja saajat kindlal viisil tegutsema ja on isiklikult huvitatud, et kirja saaja tema soovi järgi käituks. Samas ei ole kirja saaja kohustatud palutud tegevust tegema. Kokkuvõttes võib seda laadi tekstis pidada loomulikuks nii tingiva kui ka kindla kõneviisi kasutamist - valik võib varieeruda vastavalt tutvusastmele. Vähem lähedase inimese poole pöördudes on tingiva kõneviisi teksti lisamine ilmselt vajalikum kui lähedase inimese puhul. B1-tasemel olijad eelistavad selles kirjarühmas kindlat kõneviisi (kolmveerandil juhtudest) tingivale (veerandil juhtudest). Kindla kõneviisi kasutamine ei mõju küll otseselt häirivalt, siiski mõjuks tingiv kõneviis mitmel puhul viisakust lisavalt. 


\subsubsection{JUTUSTAV TEKST}

B1-taseme viimase tekstirühmana vaatlen tingiva kõneviisi kasutust jutustavates tekstides. Siin olen vaatluse alla võtnud vaid need kasutusjuhud, mil kirjutaja kommenteerib oma kirjutamisprotsessi ja mida võib vaadelda kui pöördumist teksti lugeja poole. Tingiva kõneviisi abil viisakuse väljendamise juhtude arv selles tekstitüübis on esitatud tabelis 4. Välja on toodud ka samade verbide arv kindlas kõneviisis, et võrrelda tingiva ja kindla kõneviisi kasutusdünaamikat.

Tabel 4. Tingiva kõneviisi konstruktsioonide ja samade verbide kindla kõneviisi konstruktsioonide esinemissagedus $\mathrm{BI}$-taseme jutustavates tekstides

\begin{tabular}{|l|c|c|}
\hline $\begin{array}{c}\text { Tingivas kõneviisis } \\
\text { esinevad verbid }\end{array}$ & $\begin{array}{c}\text { Tingiva kõneviisi esinemis- } \\
\text { juhtude absoluutarv }\end{array}$ & $\begin{array}{c}\text { Kindla kõneviisi esinemis- } \\
\text { juhtude absoluutarv }\end{array}$ \\
\hline tahtma & 6 & $\mathrm{I7}$ \\
\hline võima & $\mathrm{I}$ & ei ole vaadeldud \\
\hline kirjutama & $\mathrm{I}$ & $\mathrm{I}$ \\
\hline
\end{tabular}

Kokku kasutatakse tingiva kõneviisi konstruktsioone oma kirjutusprotsessi kommenteerimiseks kaheksal korral verbidega tahtma, võima ja kirjutama. Tingivat kõneviisi kasutatakse teksti alustamiseks (näide 12) ja uue mõtte sissejuhatamiseks (näide 13).

(12) See oli nii huvitav ja ma tahaksin sellest kirjutada.

(13) Tahaksin lisada, et see õpetaja tõesti panustas meie Eesti haridusse.

Kindla kõneviisi konstruktsioone kasutatakse oma kirjutusprotsessi kommenteerimiseks samade verbidega aga 18 korral ehk kaks korda tingivast kõneviisist rohkem.

Jutustavat laadi tekstides on viisakuse väljendamisel mõnevõrra teistsugune funktsioon kui eelnevalt vaadeldud kirjades. Siin mõjub viisakuse kasutamine peamiselt tagasihoidlikkuse näitamisena ja oma arvamuse mitte liigse pealesurumisena. Üldjuhul mõjub nii tingiva kui kindla kõneviisi kasutamine lugeja poole pöördumisel üsna loomulikult. 


\subsection{TINGIV KÕNEVIIS KUI VIISAKUSE VÄLJENDAJA B2-TASEMEL}

\subsection{KOLLEEGI KUTSUMINE KOOLITUSELE}

Kõige vähem kasutatakse B2-tasemel tingiva kõneviisi konstruktsioone kirjas, mille autor peab ette kujutama, et ta on lugenud huvitava koolituse reklaami ja tahab nüüd sellel koolitusel koos kolleegiga osaleda. Ta peab kirjutama kolleegile kirja: kutsuma ka teda koos endaga koolitusele ning selgitama, miks ta teda kaasa kutsub. Tingiva kõneviisi abil viisakuse väljendamise juhtude arv selles kirjarühmas on esitatud tabelis 5. Välja on toodud ka samade verbide arv kindlas kõneviisis, et võrrelda tingiva ja kindla kõneviisi kasutusdünaamikat, välja arvatud verb olema, mille puhul on raske otsustada, millised neist väljendavad viisakust ja millised mitte.

Tabel 5. Tingiva kõneviisi konstruktsioonide ja samade verbide kindla kõneviisi konstruktsioonide esinemissagedus B2-taseme tekstis „Kolleegi kutsumine koolitusele"

\begin{tabular}{|l|c|c|}
\hline $\begin{array}{c}\text { Tingivas kõneviisis } \\
\text { esinevad verbid }\end{array}$ & $\begin{array}{c}\text { Tingiva kõneviisi esinemis- } \\
\text { juhtude absoluutarv }\end{array}$ & $\begin{array}{c}\text { Kindla kõneviisi esinemis- } \\
\text { juhtude absoluutarv }\end{array}$ \\
\hline olema & 7 & ei ole vaadeldud \\
\hline võima & 4 & 10 \\
\hline soovima & 2 & $\mathrm{I}$ \\
\hline pidama & $\mathrm{I}$ & 7 \\
\hline võtma & $\mathrm{I}$ & $\mathrm{I}$ \\
\hline sobima & $\mathrm{I}$ & 0 \\
\hline
\end{tabular}

Selles kirjarühmas kasutavad B2-tasemel olijad tingiva kõneviisi konstruktsioone kokku 16 korral ehk 8 korda tuhande sõne kohta. Huvitaval kombel ei kasutata selles kirjarühmas tingivas kõneviisis kordagi verbi tahtma, mis on kokkuvõttes kõigi tingiva kõneviisi konstruktsioonide hulgas domineeriv. Tingivas kõneviisis esineb kõige sagedamini verb olema - seitse korda. Verbi olema kasutatakse nii soovituse pehmendamiseks (näide 14) kui ka lause sujuvamaks alustamiseks (näide 15), seejuures esineb olema alati ainsuse kolmanda pöörde vormis. 
(14) Küll meie sinuga seda oskame aga minu meeles lisa koolitus oleks väga kasulik.

(15) Oleks parem, nägu juba ütlesin, et sa võtaksid sõpru.

Veel kasutatakse kolleegi koolitusele kutsudes tingivat kõneviisi rohkem kui üks kord verbidega võima (näide 16) ja soovima (näide 17).

(16) Ma arvan, et meie võiksime osaleda sellel koolitusel.

(17) Ma hea meelega sooviksin et sa osalesid koolituses kutsu kedagi veel.

Kokkuvõttes ei kasutata selles kirjarühmas tingivat kõneviisi eriti palju. Kiri on mõeldud kolleegile - seega tuttavale inimesele, kes on ilmselt ka positsioonilt kirja kirjutajaga enam-vähem võrdne. Situatsiooni institutsionaalsus on keskmine. Kirjutaja soovib, et kirja saaja tuleks temaga koos koolitusele, kuid see ei ole tema jaoks vältimatult vajalik. Kirja saaja ei ole kohustatud kutsele kindlasti reageerima. Kirjutaja soov on ilmselt keskmise tugevusega ja soovi täitmine on samuti keskmise raskusega. Kirja kirjutajal ei ole ilmselt suurt õigust oodata oma soovi täitmist. Seega on tingiva kõneviisi suhteliselt vähene kasutamine selles kirjarühmas küllaltki loomulik. Tingiva ja kindla kõneviisi valik võib ilmselt osaliselt sõltuda kirja autori isikuomadustest - kas ta on oma soovide väljendamisel üldiselt pehmem või enesekindlam.

\subsubsection{KOLLEEGI ABIPALVELE ÄRAÜTLEMINE}

Kirjutaja peab ette kujutama, et on saanud kolleegilt abipalve asendada teda ühe tööpäeva jooksul, mida tal ei ole aga võimalik teha. Kirjutaja peab abipalujale eitavalt vastama ja oma otsust selgitama. Tingiva kõneviisi abil viisakuse väljendamise juhtude arv selles kirjarühmas on esitatud tabelis 6. Välja on toodud ka samade verbide arv kindlas kõneviisis, et võrrelda tingiva ja kindla kõneviisi kasutusdünaamikat. 
Tabel 6. Tingiva kõneviisi konstruktsioonide ja samade verbide kindla kõneviisi konstruktsioonide esinemissagedus B2-taseme tekstis „Kolleegi abipalvele äraütlemine"

\begin{tabular}{|l|c|c|}
\hline $\begin{array}{c}\text { Tingivas kõneviisis } \\
\text { esinevad verbid }\end{array}$ & $\begin{array}{c}\text { Tingiva kõneviisi esinemis- } \\
\text { juhtude absoluutarv }\end{array}$ & $\begin{array}{c}\text { Kindla kõneviisi esinemis- } \\
\text { juhtude absoluutarv }\end{array}$ \\
\hline võima & $\mathrm{II}$ & 17 \\
\hline tahtma & 7 & 9 \\
\hline nõus olema & 2 & 2 \\
\hline pidama & $\mathrm{I}$ & $\mathrm{I}$ \\
\hline soovitama & $\mathrm{I}$ & $\mathrm{I}$ \\
\hline minema & $\mathrm{I}$ & 3 \\
\hline asendama & $\mathrm{I}$ & 3 \\
\hline
\end{tabular}

Selles kirjarühmas kasutatakse B2-tasemel tingiva kõneviisi konstruktsioone kokku 24 korda ehk 8,5 korda tuhande sõne kohta. Kokku esineb tingivas kõneviisis seitse eri verbi, sagedamini võima ja tahtma. Kõige rohkem esineb tingiva kõneviisi konstruktsioonides verb võima: 11 korral. Samal ajal kasutatakse verbi võima kindla kõneviisi konstruktsioonides 17 korda. Võima tingiva kõneviisi konstruktsioonide abil antakse kolleegile nõu, seejuures kasutatakse nii pikka (näide 18) kui ka lühivormi (näide 19).

(18) Sellepärast mul on kahju, et ma ei saa sind aidata, kuid ma võin anda nõu, mida sa võiksid teha.

(19) Arvan, et sa võiks teda paluda ennast asendada.

Verbi tahtma konstruktsioone esineb tingivas kõneviisis 7 ja kindlas kõneviisis 9 korda. Tahtma tingiva kõneviisi konstruktsioonidega väljendatakse oma kahetsust selle üle, et abi pole võimalik osutada (näide 17) ja põhjendatakse oma otsust (näide 21).

(20) Ma tahaksin sule aidata, aga ma ei saa, sest ma pean sõida komandeeringus Rakveresse.

(21) Minu abikaasa kutsus mind ja minu vanemad sõita saunas NarvaJõesusse, ma ei või keelduda, sest seal reedel tal on juubel ja me tahaksime kõik koos ujuda basseinis, käia saunas, juua igasuguseid maitsvait kokteile ja üldse puhata. 
Verb tahtma esineb kuus korda tingiva kõneviisi pikas vormis ja üks kord lühivormis (näide 22).

(22) Proovi küsida neil ma tean täpselt, et Indrek või Andrus nõustud ja aidatud sulle võtta vaba päeva et sina saad, nagu tahaks veeta puhkus oma lemmiku inimesega.

Verbid pidama, nõus olema, soovitama, minema ja asendama esinevad tingiva kõneviisi konstruktsioonides igaüks üks-kaks korda.

Selles kirjarühmas kirjutatakse tuttavale adressaadile, kes on eeldatavalt ka sotsiaalselt positsioonilt kirja kirjutajaga enam-vähem võrdne. Situatsiooni institutsionaalsus on madal, sest kirja kirjutaja ei soovi kirja saajat midagi tegema või kuidagi reageerima panna. Kirja kirjutaja eesmärk on teatada, et tal pole võimalik kolleegi palvet täita ning põhjendada oma keeldumist nii, et omavahelised suhted ei kannataks. Kirjutajad kasutavad oma tekstides tingivat kõneviisi, kuid mitte eriti palju. Mõnikord väljendatakse tingiva kõneviisi abil oma kahetsust aitamise võimatuse pärast. Kolleegile nõu andmiseks kasutatakse nii tingivat kui ka kindlat kõneviisi, mis mõjuvad üpris loomulikult.

\subsubsection{JÄRELEPÄRIMINE KINDLUSTUSFIRMASSE}

Kirja kirjutaja ülesanne on kujutada ette, et ta soovib kindlustada endale kuuluvat kinnisvaraobjekti. Ta kirjutab kindlustusfirmasse, tutvustab oma soove ja esitab lisaküsimusi firma pakutavate teenuste ja tingimuste kohta. Tingiva kõneviisi abil viisakuse väljendamise juhtude arv selles kirjarühmas on esitatud tabelis 7. Välja on toodud ka samade verbide arv kindlas kõneviisis, et võrrelda tingiva ja kindla kõneviisi kasutusdünaamikat, välja arvatud verb olema, mille puhul on raske otsustada, millised neist väljendavad viisakust ja millised mitte. 
Tabel 7. Tingiva kõneviisi konstruktsioonide ja samade verbide kindla kõneviisi konstruktsioonide esinemissagedus B2-taseme tekstis , ärelepärimine kindlustusfirmasse"

\begin{tabular}{|l|c|c|}
\hline $\begin{array}{c}\text { Tingivas kõneviisis } \\
\text { esinevad verbid }\end{array}$ & $\begin{array}{c}\text { Tingiva kõneviisi esinemis- } \\
\text { juhtude absoluutarv }\end{array}$ & $\begin{array}{c}\text { Kindla kõneviisi esinemis- } \\
\text { juhtude absoluutarv }\end{array}$ \\
\hline tahtma & 39 & 29 \\
\hline soovima & 8 & 26 \\
\hline olema & 3 & ei ole vaadeldud \\
\hline sõlmima & 3 & 3 \\
\hline vastama & 3 & 3 \\
\hline toimuma & 1 & 2 \\
\hline saama & 1 & 12 \\
\hline
\end{tabular}

Selles kirjarühmas kasutatakse tingivat kõneviisi kokku 58 korda ehk 17,2 korda tuhande sõne kohta. Seega on tingiv kõneviis selles kirjarühmas kaks korda sagedasem kui kahes eelnevalt vaadeldus (kolleegi kutsumises kursusele ja kolleegi abipalvele äraütlemises). Tingivas kõneviisis esineb seitse verbi, seejuures domineerivad selgelt tahtma-konstruktsioonid, mida esineb kokku 39 korda. Tahtma on seejuures küllalt sage ka kindla kõneviisi konstruktsioonides 29 korda.

Tahtma-konstruktsioonid esinevad tingivas kõneviisis vaid ainsuse esimese pöörde vormis, seejuures enamasti pikas vormis. Tahtma-konstruktsioonidega väljendatakse oma soove (näited 23 ja 24) ning juhatatakse sisse järgnev küsimus (näide 25).

(23) Praegu mina tahaksin kindlustada oma korter.

(24) Enne kui koostada leping Teie firmaga, mina tahaks suhelda oma abikaasaga.

(25) Mina tahaksin küsida Teie käest, kas hind sõltub sellest, et kui palju inimest elab ühes korteris?

Tahtma-konstruktsioonidele lisaks kasutatakse selles kirjarühmas ka sünonüümseid soovima-konstruktsioone, mis aga esinevad ainult veerandil juhtudest tingivas ning kolmveerandil kindlas kõneviisis. Tingivas kõneviisis esineb soovima ainult ainsuse esimese pöörde pikas vormis ja sellega väljendatakse üldist soovi (näide 26). 
(26) Ma sooviksin saada teie firma täpsemat info.

Lisaks esinevad paaril või ühel korral tingivas kõneviisis ka verbide olema (näide 27), sõlmima (näide 28), vastama, toimuma ja saama konstruktsioonid.

(27) Oleks väga tänulik, kui Teie vastaks nendele küsimustele.

(28) Ma tahan, et lepingu sõlmiksite on viieteistkümneks aastaks pikaks.

Selle kirjarühma puhul kirjutatakse adressaadile, keda isiklikult ei tunta. Tegemist on pöördumisega mitte ühe inimese, vaid firma poole, mis tõstab kirja formaalsusastet veel. Situatsiooni institutsionaalsus on üsna kõrge. Kirjutajal on kindel ja õigustatud soov, et tema kirjale reageeritaks ja talle võimalikult sisukat infot saadetaks. Kirja saaja on kohustatud kirjale reageerima ehk vastama, seejuures ei ole tal kirjutaja soove eriti raske täita. Kokkuvõttes on tegemist tüüpilise poolametliku järelepärimiskirjaga, milles on sobiv väljendada distantseerivat viisakust. Seda B2-tasemel olijad ka teevad. Huvitav on, et kui tahtma-konstruktsioonidest esineb 57\% tingivas kõneviisis, siis soovima-konstruktsioonidest vaid 24\%. Võib oletada, et põhjuseks on soovima-konstruktsioonide tahtmakonstruktsioonidest hilisem areng.

\subsubsection{TELLIMUS RESTORANI}

Selles kirjas peavad autorid ette kujutama, et nad kavatsevad tähistada mingit pidulikku sündmust. Selle jaoks peavad nad kirjutama restoranile tellimiskirja: tellima ruumid, toidud ja meelelahutusprogrammi. Tingiva kõneviisi abil viisakuse väljendamise juhtude arv selles kirjarühmas on esitatud tabelis 8 . Välja on toodud ka samade verbide arv kindlas kõneviisis, et võrrelda tingiva ja kindla kõneviisi kasutusdünaamikat, välja arvatud verb olema, mille puhul on raske otsustada, millised neist väljendavad viisakust ja millised mitte. 
Tabel 8. Tingiva kõneviisi konstruktsioonide ja samade verbide kindla kõneviisi konstruktsioonide esinemissagedus B2-taseme tekstis „Tellimus restorani”

\begin{tabular}{|l|c|c|}
\hline $\begin{array}{c}\text { Tingivas kõneviisis } \\
\text { esinevad verbid }\end{array}$ & $\begin{array}{c}\text { Tingiva kóneviisi esinemis- } \\
\text { juhtude absoluutarv }\end{array}$ & $\begin{array}{c}\text { Kindla kõneviisi esinemis- } \\
\text { juhtude absoluutarv }\end{array}$ \\
\hline tahtma & 19 & 5 \\
\hline olema & 6 & ei ole vaadeldud \\
\hline soovima & 4 & 4 \\
\hline võima & 2 & 6 \\
\hline mängima & $\mathrm{I}$ & 2 \\
\hline tellima & $\mathrm{I}$ & $\mathrm{I}$ \\
\hline tegema & $\mathrm{I}$ & $\mathrm{I}$ \\
\hline
\end{tabular}

Selles kirjarühmas kasutatakse tingiva kõneviisi konstruktsioone B2-tasemel kõige sagedamini (kokku 34 korda ehk 27 korda tuhande sõne kohta). Tingivas kõneviisis esineb kõige sagedamini verb tahtma - 19 korda. Tahtma esineb peamiselt mitmuse ja ainsuse esimese pöörde pika vormina. Nende konstruktsioonide abil alustatakse kirja (näited 29 ja 30), kirjeldatakse oma soove lähemalt (näited 31 ja 32) ning juhatatakse sisse küsimused (näide 33).

(29) Meie firmas on aastapäev ja meie tahaksime seda pidu tähistama.

(30) Selles aastas minu tütral toimub pulmapidu ja ma tahaksin tellida sobivat kohta.

(31) Me tahaksime tellida suur saali, sest osalejate arv on 35 inimest.

(32) Peale selle me tahaksime tellida tee ja kohv, sest meie kollektiiv ei tarvitata alkohoolijoogid.

(33) Hinna kohta tahaksime teada, et kas fotograafi teenused on hinnas või me peame temale eraldi maksma.

Veel esineb tingiv kõneviis üle ühe korra verbidega olema (näide 34), soovima (näide 35) ja võima ning üksikult veel paari verbiga (näide 36).

(34) Oleks hea, kui meil oli võimalus kuulata ansambel Trühvel.

(35) Kahjuks, meid ei huvita teie ansambel Trühvel, aga sooviksime tellida fotograafi. 
(36) Ollaks väga tore, kui te teeksite seda tänase või homse päeva jooksul, või kirjute mulle meili teel.

Selleski kirjarühmas kirjutatakse võõrastele inimestele, pöördudes seejuures firma, mitte üksikisiku poole, mis tõstab kirja formaalsusastet. Ka situatsiooni institutsionaalsus on kõrge: kirjutaja esitab väga konkreetseid soove, mille täitmist ta kirja saajalt ootab ja mis on talle väga olulised. Kirja saaja jaoks on soovide täitmine keskmise raskusega - need on tema igapäevatöö tavalised tegevused.

Kokkuvõttes on tegemist tüüpilise poolametliku tellimuskirjaga, milles on sobiv väljendada distantseerivat viisakust. Seda B2-tasemel olijad ka teevad.

\subsubsection{ARUTLEV TEKST}

Siia rühma on kokku võetud nii arutlevad esseed etteantud teemal kui ka algandmetele tuginevad kokkuvõtted koos arutleva osaga. Tekstides on uuritud vaid neid konstruktsioone, millega on pöördutud otseselt lugeja poole ja mida saab seega vaadelda viisakuse väljendamise seisukohalt. Tingiva kõneviisi abil viisakuse väljendamise juhtude arv selles tekstitüübis on esitatud tabelis 9. Välja on toodud ka samade verbide arv kindlas kõneviisis, et võrrelda tingiva ja kindla kõneviisi kasutusdünaamikat, välja arvatud verb olema, mille puhul on raske otsustada, millised neist väljendavad viisakust ja millised mitte.

Tabel 9. Tingiva kõneviisi konstruktsioonide ja samade verbide kindla kõneviisi konstruktsioonide esinemissagedus B2-taseme autlevates tekstides

\begin{tabular}{|l|c|c|}
\hline $\begin{array}{c}\text { Tingivas kõneviisis } \\
\text { esinevad verbid }\end{array}$ & $\begin{array}{c}\text { Tingiva kõneviisi esinemis- } \\
\text { juhtude absoluutarv }\end{array}$ & $\begin{array}{c}\text { Kindla kõneviisi esinemis- } \\
\text { juhtude absoluutarv }\end{array}$ \\
\hline tahtma & 14 & 7 \\
\hline olema & $\mathrm{I}$ & ei ole vaadeldud \\
\hline soovima & 4 & $\mathrm{I}$ \\
\hline võima & $\mathrm{I}$ & 12 \\
\hline vastama & 2 & 0 \\
\hline küsima & $\mathrm{I}$ & 0 \\
\hline
\end{tabular}


Seda tüüpi tekstides on lugeja poole pöördumistes kasutatud peaaegu võrdselt tingivat (23 korda) ja kindlat (20 korda) kõneviisi. Populaarseimad on kokkuvõttes verbi tahtma konstruktsioonid, millest kaks kolmandikku (14 korda) esineb tingivas ja üks kolmandik (7 korda) kindlas kõneviisis). Nende konstruktsioonidega alustatakse teksti kirjutamist (näide 37) ning uut mõtet või tehakse kokkuvõte (näide 38).

(37) Kõigepealt, tahaksin öelda, et see väide on pigem õige, kui vale.

(38) Lõpuks ma tahaksin rõhutada, et meie võimalused meie kätes.

Erinevalt eelmistest tekstidest ei ole arutlevatel tekstidel otsest adressaati. Nende tekstide adressaadiks võib pidada eksamitööde hindajat või üldist kujuteldavate lugejate hulka. Seega kirjutatakse võõrastele inimestele, keda ei tunta ja kelle suhtes on distantseeriva viisakuse väljendamine sobilik. Ilmselt sõltub kõneviisi valik ka nii kirjutaja enda enesekindlusest üldiselt kui ka enesekindlusest enda konkreetsete väidete suhtes.

\section{Kokkuvõte}

Kokkuvõtteks võib öelda, et tingiva kõneviisi konstruktsioonide abil distantseeriva viisakuse väljendamine esineb nii kõigis B1-taseme ja B2-taseme kirjarühmades kui ka B1-taseme jutustavates ja B2-taseme arutlevates tekstides. Võrreldes kõiki kirju tasemete, tüüpide ja teemade kaupa, on näha, et tingiva kõneviisi kui viisakuse väljendamise esinemissagedused moodustavad küllaltki ühtlases joones tõusva rivi (vt joonis 1). B1-taseme kahes kirjarühmas (teates kolleegidele töölt lahkumise kohta ja kolleegidele saadetud kutses spordipäeval osalemiseks) on tingiva kõneviisi kasutamine kõige harvem (vastavalt 1 ja 1,3 korda tuhande sõne kohta). Keskmise sagedusega esinevad tingiva kõneviisi konstruktsioonid B1-tasemel kolleegile kirjutatud kutses, milles kirja saatja kutsub teda koos endaga kontserdile (7,5 korda tuhande sõne kohta) ning B2-taseme kahes kirjarühmas (kolleegi koolitusele kutsuvas kirjas 8 korda ja äraütlevas vastuses 
kolleegi abipalvele 8,5 korda tuhande sõne kohta. Kõige sagedasem on tingiva kõneviisi kasutamine B2-taseme kahes kirjarühmas (kindlustusfirmale saadetud järelepärimiskirjas 17,2 korda ja restorani piduliku ürituse tellimuskirjas 27 korda tuhande sõne kohta).

Tingiva kõneviisi kasutamine kirjades sõltub kultuuripõhistest keelelise viisakuse normidest ning on seotud teksti autori ja vastuvõtja tuttavusastme, sotsiaalsete positsioonide erinevuse, teksti autori soovitud teene suuruse, soovi täitmise kohustuslikkuse, soovi täitumise olulisuse ja soovi täitmise raskusega. Kõigis B1-taseme kirjarühmades kasutatakse tingivat kõneviisi distantseeriva viisakuse väljendajana vähem kui B2-taseme kirjarühmades. Samas ei pakugi kaks B1-taseme kirjarühma (kolleegidele saadetud spordipäeva kutse ja kolleegide teavitamine töölt lahkumisest) selleks eriti palju võimalusi, kuigi töölt lahkumise teates oleks tingiv kõneviis siiski sobilik kolleege lahkumispeole kutsudes. Kolmandas B1-taseme kirjarühmas (tuttavale kirjutatud kontserdikutses) esineb tingivat kõneviisi viisakuse väljendajana rohkem, kuid samas funktsioonis kasutatakse siiski üle kolme korra rohkem kindlat kõneviisi. Selles kirjarühmas sõltub tingiva kõneviisi vajalikkus eelkõige kirja saaja ja saatja omavahelisest tutvusastmest: heale tuttavale kirjutades pole vaja nii palju distantseerivat viisakust kasutada kui vähemtuttavale inimesel kutset esitades. B1-tasemel olijad ei kasuta siiski ka vähem tuttavaile kirjutades sageli tingivat kõneviisi.

B1-taseme jutustavates tekstides kasutatakse lugeja poole pöördudes tingivat kõneviisi oluliselt vähem (ühel kolmandikul juhtudest) kui kindlat kõneviisi (kahel kolmandikul juhtudest). Kokkuvõttes ei paku B1-taseme kirjatüübid ja teemad alati palju võimalusi kasutada tingivat kõneviisi viisakuse väljendamiseks. Samas ei kasuta B1-tasemel olijad ka võimaluse korral tingivat kõneviisi eriti sageli, eelistades sagedamini kindlat kõneviisi. Seega tundub, et mõnikord ei valda B1-tasemel olijad tingiva kõneviisi abil distantseeriva viisakuse väljendamist veel eriti hästi. Kohati kasutatakse tingivat kõneviisi igati sobivalt. Mitmel juhul võiks aga tingiva kõneviisi konstruktsioonide teksti lisamine muuta teksti viisakamaks. 
B2-tasemel kasutatakse tingivat kõneviisi distantseeriva viisakuse väljendajana kõigis kirjarühmades rohkem kui B1-tasemel. Kõige vähem esineb tingiva kõneviisi konstruktsioone B2-tasemel töökaaslase poole pöördumisel: kolleegi koos endaga kursusele kutsumisel ja kolleegi palvele eitava vastuse saatmisel. Oluliselt rohkem kasutavad B2-tasemel olijad tingivat kõneviisi ametiasutuste poole pöördudes: järelepärimiskirjas kindlustusfirmale ja tellimuses restorani. Seega on selgelt näha tingiva kõneviisi kui distantseeriva viisakuse väljendamise vahendi kasutuse suurem sagedus formaalsemat laadi ja kõrgema institutsionaalsusega tekstides. Ka arutlevates tekstides lugeja poole pöördudes kasutatakse B2-tasemel tingivat kõneviisi märgatavalt rohkem (kaks kolmandikku) kui kindlat kõneviisi (üks kolmandik).

Seega võimaldavad B2-taseme tekstid tingivat kõneviisi viisakuse väljendamiseks rohkem kasutada kui B1-taseme tekstitüübid ning B2-tasemel olijad kasutavad need võimalused ka ära. Kui B1-tasemel kasutatakse tingivat kõneviisi üsna vähe ning küllalt sageli muudaks tingiva kõneviisi kasutamine tekstid viisakamaks, siis B2-tasemel on viisakuse väljendamine tingiva kõneviisi abil arenenud. Tingivat kõneviisi kasutatakse palju sagedamini, mitmekesisema sõnavaraga ja vastavalt teksti formaalsusastmele ning situatsiooni institutsionaalsusele.

Artikli autorile teadaolevalt ei pöörata eesti keele kui teise keele õppematerjalides tingiva kõneviisi konstruktsioonide kasutamisele distantseeriva viisakuse väljendamisena eriti palju tähelepanu. Ometi on keeleõppijad selles B1-tasemelt B2-tasemele liikudes arenenud. Nii võib oletada, et viisakuse väljendamise arenemise põhjuseks on keele kasutuspõhine omandamine. Tingiva kõneviisi konstruktsioonid on arvatavasti arenenud õppijaid ümbritseva kultuuri- ja keelekeskkonna mõjul ning teatud määral võib tegemist olla ka ülekandega varem omandatud keelest ja kultuurist.

Uurimistulemusi saab kasutada eesti keele kui teise keele õppemetoodika ja õppematerjalide arendamiseks - keele kasutuspõhise omandamise osakaalu suurendamiseks ja tingiva kõneviisi viisakuse 
väljendamise funktsioonide tõhusamaks õpetamiseks. Tingiva kõneviisi kasutust eesti õppijakeeles tasuks ka edasi uurida: lisades uurimismaterjali hulka A2- ja C1-tasemel olijate tekste, võrrelda eri tasemetel olijate sama kirjutamisülesande täitmist või vaadelda tingiva kõneviisi kasutust eri esimese keelega õppijate tekstides.

\section{VIIDATUD KIRJANDUS}

Brown, Penelope; Stephen Levinson 1978. Universals in language usage: Politeness phenomena. - Esther N. Goody (Ed.), Questions and Politeness: Strategies in Social Interaction. Cambridge: Cambridge University Press, 56-311.

CEFR 2007 = Euroopa keeleõppe raamdokument. Õppimine, õpetamine ja hindamine. Tartu: Haridus- ja Teadusministeerium, 2007.

Curl, Traci; Paul Drew 2008. Contingency and action: a comparison of two forms of requesting. - Research on Language \& Social Interaction 41, 129-153.

De Bot, Kees; Lowie Wander, Marjolijn Verspoor 2007. A dynamic systems theory approach to second language acquisition. Bilingualism: Language and Cognition 10: 1, 7-21.

Ellis, Nick C. 2002. Frequency effects in language acquisition: a review with implications for theories of implicit and explicit language acquisition. Studies in Second Language Acquisition 24: 2, 143-188.

Ellis, Nick C.; Diane Larsen-Freeman 2009. Constructing a second language: analyses and computational simulations of the emergence of linguistic constructions from usage. Language Learning 59: S1, 93-128.

Ellis, Rod 2008. The study of second language acquisition. Oxford: Oxford University Press.

Eskildsen, Søren Wind 2008. Constructing a second language inventory. The accumulation of linguistic resources in L2 English ( $\mathrm{PhD}$ dissertation). Odense: Institute of Language and Communication University of Southern Denmark.

EVKK = Eesti vahekeele korpus, http://evkk.tlu.ee

Firth, Alan; Jihannes Wagner 1997. On discourse, communication, and (some) fundamental concepts in SLA research. Modern Language Journal 81: 3, 285-300. 
House, Juliane 2008. English as a lingua franca in Europe today. - G. Extra \& D. Gorter (Eds.), Multilingual Europe: Facts and policies. Berlin: Mouton de Gruyter, 63-85.

Kaivapalu, Annekatrin 2005. Lähdekieli kielenoppimisen apuna (Jyväskylä Studies in Humanites, 44). Jyväskylä: Jyväskylän yliopisto.

Kitsnik, Mare 2014. Verbivormid B1- ja B2-taseme kirjalikus õppijakeeles. Eesti ja soome-ugri keeleteaduse ajakiri / Journal of Estonian and Finno-Ugric Linguistics 5: 3, 9-35.

Kitsnik, Mare 2015. Tingiv kõneviis eesti B1- ja B2-taseme kirjalikus õppijakeeles kui keeleoskuse arengu näitaja. Lähivõrdlusi. Lähivertailuja 25, 137-171.

Kitsnik, Mare 2017. Modaalverbide saama ja võima konstruktsioonid B1- ja B2-taseme kirjalikus õppijakeeles kui keeleoskuse arengu näitaja. Eesti Rakenduslingvistika Ühingu aastaraamat 13, 19-36.

Kitsnik, Mare 2018. Iga asi omal ajal: eesti keele B1- ja B2-taseme verbikonstruktsioonid keeleoskuse arengu näitajana. (Doktoritöö, Tallinna ülikool). Tallinn: Tallinna Ülikooli Kirjastus.

Klaas-Lang, Birute; Renate Pajusalu 2016. Modaalkonstruktsioonid eesti ja soome palvetes. Eesti ja soome-ugri keeleteaduse ajakiri. Journal of Estonian and Finno-Ugric Linguistics (ESUKA - JEFUL) 2, 49-74.10.

Kuiken, Folkert; Ineke Vedder 2012. Syntactic complexity, lexical variation and accuracy as a function of task complexity and proficiency level in L2 writing and speaking. In A. Housen, F. Kuiken, I. Vedder (Eds.) Dimensions of L2 performance and proficiency. Complexity, accuracy and fluency in SLA. Amsterdam-Philadelphia: John Benjamins, 143-170.

Larsen-Freeman, Diane 1997. Chaos/complexity science and second language acquisition. Applied Linguistics 18: 2, 141-165.

Larsen-Freeman, Diane 2006. The emergence of complexity, fluency and accuracy in the oral and written production of five Chinese learners of English. Applied Linguistics 27: 4, 590-619.

Larsen-Freeman, Diane 2007. Reflecting on the cognitive-social debate in second language acquisition. The Modern Language Journal 91: s1, 773787.

Larsen-Freeman, Diane; Lynne Cameron 2008. Complex systems and applied linguistics. Oxford: Oxford University. 
MacWhinney, Brian 2004. A unified model of language acquisition. J. Kroll, A. De Groot (Eds.), Handbook of bilingualism: psycholinguistic approaches. Oxford: Oxford University Press.

Metslang, Helle 1999. Is the Estonian and Finnish conditional actually a conditional? - Mati Erelt (Ed.). Estonian: Typological studies III. Publications of the Department of Estonian of the University of Tartu. Tartu: Tartu University Press 97-127.

Mills, Sara 2003. Gender and politeness. Cambridge, U.K.: Cambridge University Press.

Pajusalu, Renate; Karl Pajusalu 2004. The Conditional in Everyday Estonian: Its Form and Functions. Linguistica Uralica 4, 257-269.

Pajusalu, Renate 2014. Palved eesti, soome ja vene keeles: grammatika pragmaatika teenistuses. - Eesti Rakenduslingvistika Ühingu aastaraamat 10, 241-257.

Ringbom, Håkan 2007. Cross-linguistic similarity in foreign language learning. Clevedon: Multilingual Matters LTD.

Tomasello, Michael 2003. Constructing a language: a usage-based theory of language acquisition. Harvard University Press.

Verspoor, Marjolijn; Heike Behrens 2011. Dynamic systems theory and usage-based approach to second language. - M. Verspoor, K. de Bot, W. Lowie (Eds.), A dynamic approach to second language development: methods and techniques (Language Learning \& Language Teaching, 29). Amsterdam: John Benjamins, 25-38.

Watts, Richard J. 2003. Politeness. Key Topics in Sociolinguistics. Cambridge: Cambridge Cambridge University Press. 


\section{EXPRESSING POLITENESS VIA USE OF \\ THE CONDITIONAL MOOD IN THE BI - AND B2-LEVEL TEXTS OF LEARNERS OF ESTONIAN AS A SECOND LANGUAGE}

The article addresses use of conditional mood constructions to express politeness in the written Estonian as a second language learners at B1- and B2-levels of the CEFR. The research material consists of performances in the writing tasks of the state exams of Estonian as a second language and it comes from the Estonian Interlanguage Corpus (EVKK). The material contains different types of letters and essays. There were fewer opportunities to use the conditional mood in the B1-level texts than in the B2-level texts. However, the authors of the B1-level texts preferred to use the indicative mood even where the use of the conditional would have been appropriate. In the B2-level texts there were more possibilities to use the conditional mood and the authors of these texts did take advantage of the opportunities, given the formal nature of both the text and situation. The conditional mood constructions recorded occurred most commonly in letters addressed to institutions, and so were more formal in nature and connected to more institutional situations. Thus, the use of the conditional mood to express politeness was related to cultural norms of linguistic politeness. Proficiency in use of the conditional mood to express politeness was greater at the B2-level than at the B1-level. The main reason for this may be the impact of the cultural and linguistic environment.

Keywords: second language acquisition, Estonian as a second language, written language, language constructions, language politeness 